\author{
녹용분말 급여가 성장기별 흰쥐의 성장 및 장기발육에 미치는 효과 \\ 성하균*김동균**.신형태* \\ 성균관대학교 생명공학부*, 상지대학교 동물자원학과**
}

\title{
Influence of Powdered Velvet Antler on Growth and Intestinal Organ Development in Sprague-Dawley Rats
}

\author{
H. G. Sung*, D. K. Kim** and H. T. Shin* \\ Faculty of Life Science and Technology, Sungkyunkwan University* \\ Department of Animal Science and Technology, Sangji University**
}

\begin{abstract}
The velvet antler of Korean sika deer has been used to the important resources for human health care with ginseng in Korea and Chinese. For studying on biological function of deer velvet being recorded in many ancient literatures, this experiment was conducted to evaluate the effects of powdered velvet antler on growth, feed intake, feed efficiency and intestinal organ development in growing and adult Sprague-Dawley Rats. Experiments were designed by adding amount of powdered velvet antler such as control (nonsupplementation), powdered velvet antler I (PVA I, recommended dose) and powdered velvet antler II (PVA II, thrice recommended dose). The recommended dose of powdered velvet in this experiment was calculated with metabolic body weight of rats, which based on the recommended amounts for 70 $\mathrm{kg}$ of human. The growths of growing and adult rats generally appeared advantage in PVA supplementation. The final body weight of control, PVA I and II were respectively $470 \pm 39.00 \mathrm{~g}$, $478 \pm 30.33 \mathrm{~g}$ and $475 \pm 22.72 \mathrm{~g}$ in growing rats, and $485 \pm 38.50 \mathrm{~g}, 521 \pm 38.67 \mathrm{~g}$ and $508 \pm 34.44 \mathrm{~g}$ in adult rats. The average daily feed intake were not significantly influenced but the feed efficiency ratios (feed/gain) were improved by PVA supplementation. The feed/gain ratios of control, PVA I and II were respectively 5.99, 5.47 and 5.54 in growing rats, and 9.04, 7.73 and 8.18 in adult rats. In case of developments of liver, heart, kidney and stomach, we obtained favorable results in both PAC I and II, but their results were not significantly different according to amount of PVA supplementation. Because liver and heart are important organs in the circulation of blood, their favorable effects suggest that velvet antler may have factors contributing hematopoiesis. Conclusively, supplementation of powdered velvet antler resulted in an improved growth, feed efficiency and development of some intestinal organs in growing and adult rat. Even if further investigation of dose in human health care are should be performed, this experiment appeared the best desirable results in PVA I, recommended dose of powdered velvet antler.
\end{abstract}

(Key words : Velvet Antler, Sika Deer, Sprague-Dawley Rats)

\footnotetext{
Corresponding author : H. T. Shin, Dept. of Food and Life Science, Faculty of Life Science and Technology, Sungkunkwan University, Suwon, 440-746, South Korea, Tel : +82-31-290-7804, E-mail : htshin@skku.edu.
} 
$\mathrm{I}$ 서 론

녹용은 우리나라와 중국에서 인삼과 함께 고귀한 한방강장제로 사용되고 있는 것으로서 神農本草經 孫 1976)에 최초로 기록되기 시 작하여 本草剛目 李

東醫寶鑑 許 1981)에 녹용의 성상 및 효능에 관하여 기재 되어 있으나 과학적 실험 근거가 부족한 실정 이다.

\section{大韓藥典生藥規格集梅花鹿} (Cervus nippon) 또는 馬鹿 (Cervus elaphus) 및 同屬近緣動物 (사슴과 Cervidae)의 털이 밀생되고 골질화되지 않은 어린뿔이다” 라고 정의되어 있고, 東醫寶鑑 許 1981)에 녹용 의 강장작용, 생장발육 촉진작용, 신경쇠약 치료 작용, 심부전증 치료 작용, 오장육부의 기능항진작용 등 다양한 효용이 있는 것으 로 수록되어 있으며, 특히 허약 체질의 보혈 강장, 정력증진, 지구력 증강에 효능이 알려 져 고귀한 강장제로서 우리나라와 중국 등 에서 널리 상용되고 있다 (한 등, 1994). 녹 용의 규격 규정 (The ministry of health and welfare, 1998)에는 wet basis로 회분량이 25\% 이하의 골질화되지 않은 사슴뿔은 녹용, 회 분 함량이 $25.01 \%$ 이상 $35 \%$ 이하의 약간 골 질화된 어린뿔은 녹용각, 회분 함량이 $35 \%$ 이상의 골질화된 뿔은 녹각으로 정의 하였 다. 안 (1994)은 산지별 녹용의 영양가치에 대한 연구에서 우리나라 꽃사슴 녹용의 조 회분은 $39.95 \%$ 로서 중국산 매화녹용 (34.43\%)과 뉴질랜드산 레드디어의 녹용 (31.73\%) 보다 약간 높았다고 보고한 바 있 으며. 김과 류 (2000)는 회분, $\mathrm{Ca}, \mathrm{P}, \mathrm{Cu}, \mathrm{Fe}$ 함량 및 $\mathrm{Ca} / \mathrm{ash}(\%), \mathrm{Ca} / \mathrm{P}, \mathrm{Ca} / \mathrm{F}$ 비가 녹용의 품질 지표로 사용될 수 있는 가능성도 제시 한 바 있다.

허 (1959)가 "녹용에 관한 연구를 처음 발표 함으로서 학계에 새로운 관심을 일으켰으며, 지금까지 녹용의 성분은 leucine, methionine, threonine, lysine, glycine, proline, glutamate, cysteine, phenylalanine, histidine, valine, isoleucine, tyrosine, arginine 등의 16 종의 아미노산과 $\mathrm{Ca}, \mathrm{Mg}, \mathrm{Fe}, \mathrm{Cu}, \mathrm{Zn}, \mathrm{Mn}, \mathrm{Al}, \mathrm{As}, \mathrm{P}, \mathrm{Na}, \mathrm{Ni}, \mathrm{Pb}$, $\mathrm{Ba}, \mathrm{Cr}$ 등 14 종의 미량광물질에 대하여 보고하 였고(김 등, 1973; 배, 1975; 용, 1976a, b; 이 등, 1992; 안, 1994), 김 등(1975)은 녹용의 velvet layer와 녹각에서 arabinose, deoxyribose, ribose, xylose, fructose, galactose, glucose, mannose 와 같은 8종의 당을 분석하였다. 또한 녹용에서 sphingomyelin, ganglioside, pantocrine, proteolipid 등이 분석되었다(안, 1994; 한과 전, 1994; Jhon 등, 1999).

그러나 지금까지 녹용의 약효를 대표할만 한 성분은 밝혀지지 않았으나 허 등(1959)은 녹용을 급여한 실험쥐의 성장이 촉진되었다 고 발표하였으며, 배(1975, 1976)는 녹용급여가 병아리의 증체량, 사료요구율, 장기 발육에 대하여 좋은 영향을 주었다고 보고하였다. 그 리고 이밖에 녹용 급여 및 녹용추출물 투여 가 당대사 증진효과(오와 이, 1987; 노, 1988), 면역계의 활성 증강효과(신 등, 1989; 노, 1988), 스트레스와 독성저항 증대효과(한, 1970 ; 강, 1970; 김, 1989) 및 노화 방지 효과 (Wang 등, 1988; 王 徐 등, 1992; Chen 등, 1992) 등에 대하여 연구가 수행되 어졌다.

그러므로 본 연구는 이상과 같은 녹용의 성상과 한방강장제로서 효능을 과학적 사양 실험을 통하여 증명하기 위해 제품화 된 국 산 녹용분말을 이용하여 흰쥐의 성장시기별 즉, 성 성숙전과 후에 급여한 녹용의 효능을 관찰하기 위하여 5주령된 어린쥐와 10주령된 큰쥐의 체중변화, 사료요구율 및 장기발육에 미치는 영향에 대하여 조사하였다.

\section{재료 및 방법}

\section{1. 실험동물 및 사양관리}

본 실험은 국내산 꽃사슴의 녹용을 가지고 
녹용의 효능을 검증하기 위하여 3 주령과 8 주 령의 수컷 72 마리의 Sprague-Dawley종 흰쥐 를 구입하여 사육하였다. 실험동물의 사양관 리는 본 실험전 2주일간의 예비기간을 두어 실험사료 및 Cage에 적응 시켰으며, 사육실 의 명암 조절은 12 시간 주기 (08:00-20:00 점 등)로 조절하였으며, 매일 일정한 시간 (17:00) 에 실험 사료와 물을 급여하여 자유급식 하 였다.

\section{2. 실험사료 및 설계}

전체 실험기간은 10 주이었으며 첨가물 급 여 수준에 따라 대조구, 녹용분말 I구 (PVA I; powdered velvet antler I)와 II구 (PVA II; powdered velvet antler II)로 구분하였는데 각 처리구별 실험동물은 평균체중이 비슷한 것 으로 완전임의배치법으로 12 두씩 배치하였다. 그리고 실험에 사용된 녹용분말은 골질화되 지 않은 솜털이 무성한 상태의 녹용을 냉동 건조 후 분세기를 이용 분말 형태로 만들어 준비하였다.

대조구는 녹용분말을 첨가하지 않은 시판 실험동물용 배합사료를 급여하였다. 그리고 녹용분말 I구는 권장량을 급여하였으며, 녹용 분말 II구는 권장량의 3 배를 혼합하여 급여하 였다. 즉 녹용분말 첨가량은 동의보감 (허, 1991)의 처방을 근거로 하여 몸무게가 $70 \mathrm{~kg}$ (대사체중: $24.2 \mathrm{~kg}$ )인 성인에게 권장된 녹용분 말 $7.5 \mathrm{~g} / \mathrm{day}$ 를 기준으로 하여 실험쥐의 대사 체중 $\left(\mathrm{Wkg}^{0.75}\right)$ 을 적용하여 계산하였다. 이때 계산된 실험쥐의 대사 체중 당 녹용분말의 첨가량은 $0.3099 \mathrm{mg}$ 으로, 이를 본 연구에서는 권장량이라 명명하여 사용하였다. 처리구별 실험사료 및 물은 자유급식 하였으며 녹용분 말을 완전히 혼합하여 $2^{\circ} \mathrm{C}$ 냉장 보관하여 급여하였다. 적응기간을 제외한 본 실험기간 은 10 주간이었으며, 각 처리구별 실험 5 주말 과 10 주말에 각각 6 두씩을 해부하여 조사항 목을 측정하였다.

\section{3. 조사항목 및 분석방법}

(1) 실험 기초배합사료 및 녹용분말의 성분 분석

실험용 기초배합사료의 일반분석은 A.O.A.C. (1995) 방법에 의하여 분석하였는데 조단백질은 KJELTEC AUTO 1030 Analyzer을 이용하여 분 석하였고, 조섬유는 FIBER TEC SYSTEM 1020 Hot Extractor를 사용하였다. 그리고 그 결과 는 Table 1 과 같다.

녹용분말의 일반성분은 A.O.A.C. (1995) 방 법에 의하여 분석하였고, 아미노산 함량은 HITACHI 835 Amino Acid Analyzer에 의하여, 광물질 함량은 HITACHI Z-6000 Atomic Absorption Spectrophotormeter에 의하여 분석하였는 데 그 결과는 Table 2와 같다.

(2) 사료섭취량 및 증체량

사료섭취량은 매일 사료를 급여한 후 그 다 음날 같은 시간에 남은 사료량을 측정하여 사 료섭취량을 계산하였으며, 실험쥐의 증체량은 1 주 간격을 두고 체중을 칭량하였다.

Table 1. Chemical composition of the basal diet for rats

(unit : \%)

\begin{tabular}{lcc}
\hline \multicolumn{1}{c}{ Items } & As-fed basis & Dry matter basis \\
\hline \hline Dry matter & 88.90 & 100.00 \\
Crude protein & 22.06 & 24.81 \\
Crude fiber & 2.70 & 3.04 \\
Crude fat & 4.64 & 5.22 \\
Crude ash & 6.44 & 7.24 \\
Ca & 0.60 & 0.67 \\
$\mathrm{P}$ & 0.40 & 0.45 \\
\hline
\end{tabular}

(3) 장기 무게 측정

장기 무게를 조사하기 위하여 실험 5 주말 그 리고 실험 종료시 (10주말) 해부하여 심장, 간장, 신장, 위장을 적출하여 ice-cold physiological 
Table 2. Chemical composition of powdered velvet antler

\begin{tabular}{lclc}
\hline Items & DM basis & Items & DM basis \\
\hline \hline Proximate analysis (\%) & \multicolumn{3}{c}{ Amino acids (\%) } \\
Dry matter & 92.2967 & Cysteine & 0.5200 \\
Crude ash & 34.3049 & Methionine & 0.6502 \\
Crude protein & 61.7219 & Aspartate & 3.3718 \\
Crude fat & 13.3692 & Threonine & 1.3524 \\
Crude fibre & 2.3231 & Serine & 1.5705 \\
& & Glutamate & 4.8597 \\
\hline Minerals & & Glycine & 8.3312 \\
Ca (\%) & 12.9257 & Alanine & 4.6613 \\
P (\%) & 5.9157 & Valine & 2.5454 \\
K (\%) & 0.3890 & Isoleucine & 1.3143 \\
Na (\%) & 0.2871 & Leucine & 2.6957 \\
Mg (\%) & 0.2817 & Tyrosine & 0.8352 \\
Fe (mg/kg) & 309.87 & Phenylalanine & 1.8455 \\
Mn (mg/kg) & 270.87 & Lysine & 2.7479 \\
Zn (mg/kg) & 52.87 & Histidine & 1.6133 \\
Cu (mg/kg) & 13.54 & Arginine & 2.8372 \\
& & Proline & 4.6208 \\
\hline
\end{tabular}

saline $(0.9 \% \mathrm{NaCl})$ 에서 혈액과 체액을 거즈로 제거한 후 wet weight를 측정하였다. 심장과 위 장의 순수 무게를 측정하기 위하여 심장 내 혈 액과 위장 내용물을 완전히 제거한 후 중량을 칭량하였다.

\section{4. 통계분석}

모든 자료는 PC-SAS (SAS Institute, 1988)를 이용하여 분산분석을 실시하였고, 유의성 검정 은 Duncan's multiple range test (Duncan, 1955)로 처리하였다.

\section{III 결과 및 고찰}

\section{1. 체중변화}

생후 5주령된 어린쥐와 10 주령된 큰쥐에게
녹용분말을 각각 10 주간 급여하였을 때 체중변 화는 Fig. 1, 2 그리고 Table 3과 같다.

Fig. 1과 같이 생후 5주령된 어린쥐의 전 실 험 기간 동안 체중변화 곡선을 볼 때 각 처 리구간 큰 차이를 보이지 않았지만, 실험 시 작시 모든 처리구의 평균 체중이 $186 \pm$ $34.26 \mathrm{~g}$ 에서 10 주 후의 녹용분말 I구와 II구의 체중은 각각 $478 \pm 30.33 \mathrm{~g}$ 과 $475 \pm 22.72 \mathrm{~g}$ 으로 대조구의 $470 \pm 39.00 \mathrm{~g}$ 에 비하여 다소 높은 체중을 보였다 (Table 3). 그리고 실험 6주째 부터 체중은 장기발달을 관찰하기 위해 처리 구별 각각 6두씩 희생시킨 후 남은 실험쥐를 칭량한 체중이며, 실험 6주와 7주의 모든 실 험구에서 미약한 증체와 체중 감소 현상이 나타났는데 이는 고온 다습한 기후의 환경 변화에 대한 어린쥐의 적응능력 부족과 실험 두수의 감소로 인한 개체의 차에서 유래된 것으로 사료된다. 
Table 3. Effects of powered velvet antler supplementation on average daily gains, average daily feed intake and feed efficiency ratio of growing and adult rats

\begin{tabular}{lccc}
\hline Items & Control & I & II \\
\hline \hline Growing rats & & & \\
Initial body weight (g) & $186.17 \pm 34.29$ & $186.56 \pm 33.31$ & $186.60 \pm 35.17$ \\
Final body weight (g) & $470.00 \pm 39.00$ & $478.33 \pm 30.33$ & $475.17 \pm 22.72$ \\
Average daily gains (g) & 4.06 & 4.17 & 4.13 \\
Average daily feed intake (g) & $24.28 \pm 2.70$ & $22.79 \pm 0.99$ & $22.86 \pm 1.07$ \\
Feed/Gain ratio & 5.99 & 5.47 & 5.54 \\
\hline Adult rats & $303.00 \pm 26.33$ & $308.83 \pm 22.19$ & $304.08 \pm 19.76$ \\
Initial body weight (g) & $485.00 \pm 38.50^{\mathrm{a}}$ & $521.00 \pm 38.67^{\mathrm{b}}$ & $508.33 \pm 36.44^{\mathrm{a}}$ \\
Final body weight (g) & 2.60 & 3.04 & 2.91 \\
Average daily gains (g) & $23.47 \pm 2.48$ & $23.50 \pm 1.31$ & $23.84 \pm 1.56$ \\
Average daily feed intake (g) & 9.04 & 7.73 & 8.18 \\
Feed/Gain ratio & & & \\
\hline a,b Values with different superscripts in the same row significantly differ (I $<0.05)$. &
\end{tabular}

${ }^{a, b}$ Values with different superscripts in the same row significantly differ $(\mathrm{I}<0.05)$.

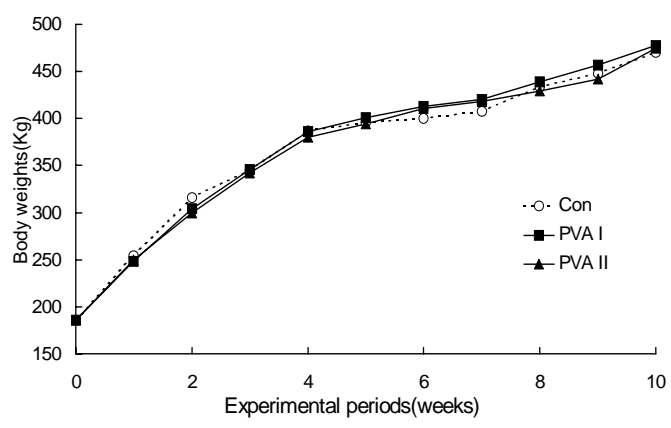

Fig. 1. Effects of powdered velvet antler supplementation on the body weights of growing rats.

PVA I: Powdered velvet antler I.

PVA II : Powdered velvet antler II.

생후 10 주령된 큰쥐의 체중은 Fig. 2와 같 이 녹용을 섭취한 실험쥐에서 전 실험기간 동안 좋은 성장을 보였다. 녹용분말을 급여한 두 처리구 모두 실험 1주 이후부터 무처리구 에 비하여 높은 체중을 나타나기 시작하여 2 주와 3 주째에 현격히 증가하였으며 실험 전 기간 높은 발육곡선을 보였다. 실험 시작시 평균 체중이 대조구, 녹용분말 $\mathrm{I}$ 구와 $\mathrm{II}$ 구는

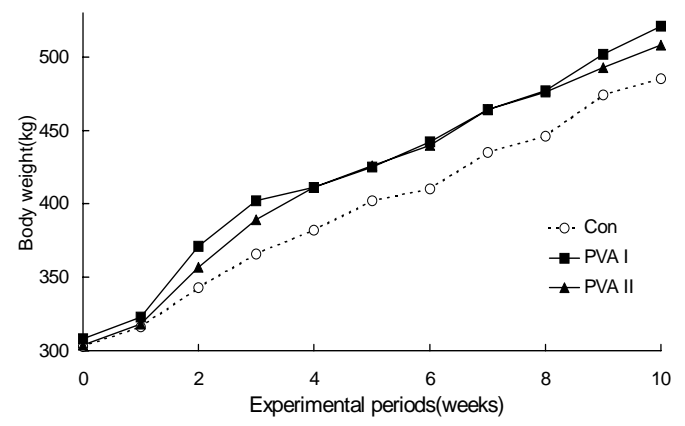

Fig. 2. Effects of powdered velvet antler supplementation on the body weights of adult rats.

각각 $303 \pm 26.33 \mathrm{~g}, 308 \pm 22.19 \mathrm{~g}$ 그리고 $304 \pm$ $19.76 \mathrm{~g}$ 에서 시작하였으며, 실험 종료시 대조 구의 체중 $485 \pm 38.50 \mathrm{~g}$ 에 비하여 녹용분말 I 구에서 유의적으로 증가된 체중 $(521 \pm 38.67 \mathrm{~g})$ 을 보였으며(I<0.05), 녹용분말 II구에서도 대조구에 비하여 높은 체중 $(508 \pm 36.44 \mathrm{~g})$ 을 보였다(Table 3).

이상과 같은 결과는 허 등(1959)의 “녹용이 실험용 흰쥐의 성장에 미치는 영향에 관한 연 구”와 배(1975, 1976)의 “병아리 발육에 미치는 
녹용분말의 효과”에 관한 연구에서 보고한 결 과와 유사한 경향을 보였다.

\section{2. 사료섭취량 및 사료요구율}

각 처리구별 실험기간 중 어린쥐와 큰쥐의 사료섭취량과 사료요구율은 Table 3과 같다.

녹용분말 급여가 실험쥐의 일일 평균 사료섭 취량에 특별한 영향을 주지 않았으며, 어린쥐 의 경우 무처리구가 녹용분말을 급여한 처리구 보다 일일 평균 사료섭취량이 다소 많았으나 통계적 유의성이 없었으며, 큰쥐의 경우는 비 슷한 사료섭취량을 보였다. 사료 섭취량은 사 료의 특성과 환경적 요인에 의해 영향을 많이 받는 것으로 본 실험은 배 (1975)의 연구에서 녹용 급여 수준에 따라 병아리의 사료섭취량이 증가하였다고 보고한 실험과는 다른 결과를 보 였다.

사료요구율은 어린쥐의 경우 대조구의 5.99 에 비하여 녹용분말 $\mathrm{I}$ 구와 $\mathrm{II}$ 구는 각각 5.47 과 5.54 로 좋은 사료효율을 보였으며, 큰쥐의 경우 대조구의 사료요구율 9.04에 비하여 녹용분말 I
구와 II구는 각각 7.73 과 8.18 로 사료효율이 현 저히 좋았고, 어린쥐와 큰쥐에서 모두 녹용분 말 II구 보다는 녹용분말 I구에서 사료효율이 좋게 나타났다. 이 같은 시험결과는 녹용분말 급여가 병아리의 사료효율을 증진시켰다고 보 고한 배 (1975)의 연구결과와 일치하며, 본 실 험 결과를 볼 때 녹용분말을 과잉 급여한 실험 쥐보다는 권장량을 급여한 실험쥐에서 더 큰 사료효율 증진을 보였다.

이상과 같이 녹용분말구의 사료효율 증진 효 과는 본 실험의 장기 발육에서 나타나듯이 녹 용분말 급여로 인한 장기의 양호한 발육뿐만 아니라, 동시에 이들 장기의 기능 향상과 영양 대사 증진에 의해 기인된 현상으로 사료된다. 이러한 녹용의 생리활성 기능 및 효능은 여러 문헌에 기록되어 있다 (이와 안, 1987; 한 등, 1994).

\section{3. 장기발육}

(1) 간장과 심장

녹용분말 급여가 어린쥐와 큰쥐의 간장과 심

Table 4. Effects of powered velvet antler supplementation on intestinal organ weight of growing rats

(unit : g)

\begin{tabular}{cccc}
\hline Items & Control & I & II \\
\hline \hline Liver & & & \\
5 weeks & $12.24 \pm 1.69(0.031)$ & $12.61 \pm 1.12(0.032)$ & $13.46 \pm 0.88(0.035)$ \\
10 weeks & $13.62 \pm 2.64(0.029)$ & $13.71 \pm 0.76(0.029)$ & $13.93 \pm 1.76(0.030)$ \\
\hline Heart & $1.20 \pm 0.10(0.003)$ & $1.21 \pm 0.07(0.003)$ & $1.20 \pm 0.06(0.004)$ \\
5 weeks & $1.54 \pm 0.10(0.003)$ & $1.63 \pm 0.17(0.003)$ & $1.62 \pm 0.17(0.003)$ \\
10 weeks & & & \\
\hline Kidney & $2.79 \pm 0.21(0.007)$ & $2.76 \pm 0.27(0.007)$ & $2.81 \pm 0.18(0.007)$ \\
5 weeks & $3.02 \pm 0.22(0.006)$ & $3.06 \pm 0.27(0.006)$ & $3.03 \pm 0.10(0.006)$ \\
10 weeks & $1.51 \pm 0.22(0.004)$ & $1.49 \pm 0.17(0.004)$ & $1.47 \pm 0.17(0.004)$ \\
\hline Stomach & $1.73 \pm 0.13(0.004)$ & $1.83 \pm 0.11(0.004)$ & $1.71 \pm 0.22(0.004)$ \\
\hline weeks & & &
\end{tabular}

( ) : Organ weight per body weight, g/kg. 
Table 5. Effects of powered velvet antler supplementation on intestinal organ weight of adult rats

(unit : g)

\begin{tabular}{cccc}
\hline Items & Control & I & II \\
\hline \hline Liver & & & \\
5 weeks & $13.13 \pm 0.70(0.032)$ & $13.38 \pm 1.44(0.031)$ & $14.36 \pm 1.62(0.033)$ \\
10 weeks & $14.45 \pm 1.17(0.030)$ & $15.11 \pm 1.23(0.029)$ & $14.45 \pm 1.53(0.028)$ \\
\hline Heart & $1.45 \pm 0.20(0.003)$ & $1.45 \pm 0.09(0.003)$ & $1.51 \pm 0.14(0.003)$ \\
5 weeks & $1.51 \pm 0.13(0.003)$ & $1.67 \pm 0.16(0.003)$ & $1.61 \pm 0.12(0.003)$ \\
10 weeks & & & \\
\hline Kidney & $2.70 \pm 0.22(0.007)$ & $2.72 \pm 0.24(0.006)$ & $2.90 \pm 0.17(0.007)$ \\
5 weeks & $2.84 \pm 0.18^{\mathrm{a}}(0.006)$ & $3.36 \pm 0.22^{\mathrm{b}}(0.006)$ & $3.38 \pm 0.17^{\mathrm{b}}(0.006)$ \\
10 weeks & & & \\
\hline Stomach & $1.61 \pm 0.19(0.004)$ & $1.73 \pm 0.05(0.004)$ & $1.69 \pm 0.18(0.004)$ \\
5 weeks & $1.86 \pm 0.21(0.004)$ & $2.08 \pm 0.19(0.004)$ & $2.12 \pm 0.14(0.004)$ \\
10 weeks & & & \\
\hline
\end{tabular}

${ }_{\mathrm{a}, \mathrm{b}}$ Values with different superscripts in the same row significantly differ $(\mathrm{P}<05)$.

( ) : Organ weight per body weight, g/kg

장 발육에 미치는 영향은 Table 4와 5에서 보 는 것과 같이 일반적으로 녹용분말 급여구가 전체적으로 다소 높은 경향을 보였으나 유의적 차이는 발견되지 않았다.

어린쥐의 간장 발육은 처리구간에 큰 차이가 없었으며, 큰쥐의 경우에도 처리구간 특별한 경향을 발견할 수 없었으나 실험 5 주의 녹용분 말 $\mathrm{II}$ 구와 실험 10 주의 녹용분말 $\mathrm{I}$ 구에서 다소 높은 수치를 보였다.

심장 발육은 실험 10 주의 어린쥐와 큰쥐에서 녹용분말 급여구 모두에서 무처리구에 비하여 다소 좋은 발육을 보였으나, 5주는 어린쥐의 녹용분말 I구 그리고 큰쥐의 녹용분말 II구에서 다소 높은 결과를 보였다.

그리고 체중대비 장기의 무게를 비교하였 을 때 심장/체중의 경우 어린쥐의 녹용분발 $\mathrm{II}$ 구를 제외한 실험쥐의 모든 실험구에서 일 정한 수준 $(0.003 \mathrm{~g} / \mathrm{kg})$ 을 보였으나, 간장/체중 의 경우는 어린쥐 5 주의 녹용분말 I 과 II구, 10 주의 녹용분말 II구 및 큰쥐 5 주의 녹용분 말 II구에서 무처리구와 다른 처리구에 비하
여 다소 높은 수준을 보였다.

이상의 결과와 같이 녹용분말 급여로 인한 간장과 심장 무게가 무처리구에 비하여 다소 증가하였다는 사실은 녹용분말 급여가 간장과 신장의 발육에 좋은 영향을 줄 수 있다고 추론 되며, 본 실험의 결과는 배 (1976)의 병아리 장 기발육에 대한 실험결과와 유사하며, 이들은 혈액과 중요한 관계가 있는 장기로서 녹용분말 이 조혈작용 및 영양소 대사 등에 좋은 영향을 줄 수 있다는 것을 시사한다고 볼 수 있다. 그 리고 어린쥐와 큰쥐의 5 주에서 녹용분말 $\mathrm{II}$ 의 체중대비 간장의 무게가 높은 경향을 보였다는 사실은 어린쥐의 경우 녹용분말의 과량급여는 간장의 발육에 큰 영향을 줄 수 있다는 가능성 을 시사한다.

\section{(2) 신장과 위장}

녹용분말 급여가 신장과 위장 발육에 미치는 영향은 Table 4 그리고 5 와 같다.

녹용분말을 급여하였을 때 어린쥐의 신장 발육은 녹용분말 $\mathrm{I}$ 구의 5 주를 제외한 다른 
모든 처리구에서 다소 높은 결과를 보였으며, 실험 5주는 녹용분말 II구가 녹용분말 I구 보 다 높았으나 10 주는 녹용분말 $\mathrm{I}$ 구가 녹용분 말 II구보다 다소 높은 경향을 보였다. 그러 나 모든 처리구간 차이는 통계적 유의성을 보이지 않았다.

큰쥐의 신장 발육은 어린쥐의 실험 결과와 유사하게 녹용분말을 급여한 모든 처리구에서 더 좋은 신장 발육을 보였고, 특히 실험 10 주 의 각각 녹용분말 $\mathrm{I}$ 구와 $\mathrm{II}$ 구는 각각 $3.36 \pm$ $0.12 \mathrm{~g}$ 과 $3.38 \pm 0.17 \mathrm{~g}$ 로 무처리구의 $2.84 \pm 0.18 \mathrm{~g}$ 에 비하여 유의적으로 높은 결과를 보였다 (( 0.05).

위장 발육에 있어 녹용분말을 급여하였을 때 모든 처리구 사이에 유의적 차이는 없었으나, 어린쥐는 대조구에 비하여 10 주의 녹용분말 I 구을 제외한 다른 모든 처리구에서 다소 낮은 경향을 보인 반면에 큰쥐의 경우 녹용분말을 급여한 모든 처리구가 무처리구에 비하여 좋은 발육을 보였다.

그리고 체중대비 신장 및 위장의 무계는 모 든 실험쥐에서 일정한 수준, 즉 신장/체중의 경 우 어린쥐 및 큰쥐 모두 5 주는 $0.007 \mathrm{~g} / \mathrm{kg}$ 그 리고 10 주는 $0.006 \mathrm{~g} / \mathrm{kg}$ 를 보였으며 체중대비 위장의 무게는 어린쥐 및 큰쥐의 모든 실험구 가 $0.004 \mathrm{~g} / \mathrm{kg}$ 를 보였다.

\section{IV 요 약}

우리나라와 중국에서 인삼과 함께 고귀한 한방 강장제로 사용되고 있는 녹용의 효능에 대하여 알고자 본 실험은 녹용분말을 급여하 였을 때 흰쥐의 발육에 미치는 영향에 대하 여 고찰하고자 실시하였다. Sprague-Dawley종 5 주령의 어린쥐와 10 주령의 큰쥐를 각각 12 두씩 처리구별로 임의 배치하였고, 녹용분말 을 급여하지 않는 대조구, 녹용분말 I구 (권 장량) 그리고 녹용분말 II구 (권장량 3배)로 구분하여 10 주간 사육하였으며 실험쥐의 성 장발육, 사료섭취량, 사료요구율 및 장기발육
에 대하여 조사하였다. 그리고 본 실험의 녹 용분말 권장량은 몸무게가 $70 \mathrm{~kg}$ (대사체중: $24.2 \mathrm{~kg}$ )인 성인에게 권장된 녹용분말 7.5 $\mathrm{g} / \mathrm{day}$ 를 기준으로 하여 실험쥐의 대사체중 $\left(\mathrm{Wkg}^{0.75}\right)$ 를 적용하여 계산하였다. 실험쥐들에 대한 성장발육은 어린쥐의 녹용분말 급여구 에서 실험 종료시 체중이 다소 좋게 나타났 지만 처리구간에 현격한 차이는 발견되지 않 았다. 그러나 큰쥐의 경우는 녹용분말을 급 여 I구와 II구 모두에서 녹용분말을 급여하지 않은 실험쥐 보다 전 실험 기간동안 좋은 성 장을 보였으며, 실험 종료시 대조구, 녹용분 말 $\mathrm{I}$ 구와 $\mathrm{II}$ 구의 체중은 각각 어린쥐가 $470 \pm 39.00 \mathrm{~g}, 478 \pm 30.33 \mathrm{~g}$ 과 $475 \pm 22.72 \mathrm{~g}$ 그리 고 큰쥐가 $485 \pm 38.50 \mathrm{~g}, 521 \pm 38.67 \mathrm{~g}$ 과 $508 \pm$ $34.44 \mathrm{~g}$ 으로 어린쥐 및 큰쥐 모두 녹용분말 I 구의 체중이 가장 높았다. 사료섭취량은 녹 용분말 급여에 의하여 특별한 영향을 받지 않았으며, 사료요구율은 대조구, 녹용분말 I 구와 II구에서 각각 어린쥐가 5.99, 5.47과 5.54 , 그리고 큰쥐가 9.04, 7.73와 8.18로 어린 쥐와 큰쥐 모두에서 녹용분말 급여구에서 사 료효율이 좋았으며 권장량의 녹용분말을 급 여하였을 때 가장 좋은 사료효율을 보였다. 그리고 장기 무게에 있어서는 처리구간 큰 차이를 보이지는 않았지만 녹용분말을 급여 한 어린쥐와 큰쥐의 간장, 심장 신장 및 위 장의 발육이 좋은 경향을 보였으며 녹용분말 급여량을 달리함에 따라 장기 발육에 미친 영향에 대한 특별한 경향은 발견하지 못하였 다. 또한 간장과 신장은 혈액과 중요한 관계 가 있는 장기로 녹용분말 급여가 이들 발육 에 영향을 주었다는 결과는 녹용의 조혈 작 용에 대한 가능성을 시사한다고 볼 수 있다. 결론적으로 녹용분말 급여가 어린쥐와 큰쥐 의 성장, 사료요구율 및 장기 발육에 좋은 영향을 주었으며, 녹용 급여량에 대한 세부 적 연구는 더 필요하지만 본 실험에서는 권 장량을 급여하였을 때 더 바람직한 결과를 얻었다. 
$\mathrm{V}$ 사 사

본 연구에 사용된 모든 재료는 한국양록축산 협동조합의 지원을 받아 이루어진 것으로 이 지면을 빌어 한국양록축산협동조합에 감사를 드립니다.

\section{$\mathrm{VI}$ 인 용 문 헌}

1. AOAC. 1995. Official Methods of Analysis (16th Ed.). Association of Official Analytical Chemists. Arlington, Virginia.

2. Chen, X., Jia, Y. and Wang, B. 1992. Inhibitory effects of extract of pilose antler on monoamine oxigase in aged mice. Chung Kuo Chung Yao Tsa Chih. 17:107-110

3. Duncan, D. B. 1955. Multiple range and multiple F test. Biometrics. 11:1-42.

4. Jhon, G. J., Park, S. Y., Han, S. Y., Lee, S., Kim, Y. and Chang, Y. S. 1999. Studies of the chemical structure of gangliosides in deer antler, cervus nippon. Chem. Pharm. Bull. (Tokoy). 47:123-127.

5. SAS. 1988. User's Guide : Statistics, Version 6 Edition, SAS Inst., Cary, NC.

6. The ministry of health and welfare. 1998. The specification of traditional medicine except the index of Korea Drug. The ministry of health and welfare announcement No. 1998-33.

7. Wang, B. X., Zhao, X. H., Yang, X. W., Kaneko, S., Hattoti, M., Namba, T. and Nomura, Y. 1988. Identification of the inhibitor for monoamine oxidase B in the extract from deer antler. 和漢 醫學學會誌 5:116-122.

8. 강우석. 1970. 녹용이 온열, 한랭 또는 전력을 받은 흰쥐에 미치는 영향. 카 톨릭의대논문집. 19:1-9.

9. 김영은, 이승기, 윤웅찬. 1973. 동물 경조직 단 백질 성분의 조성과 생리기능에 관한 연구. 한 국생화학회지. 6:13-19.

10. 김영은, 이승기, 윤웅찬, 김정숙. 1975. 녹용의 약효 성분에 관한 연구(I). 녹용, 녹각, 고래코 연골, 상어 척수 연골의 화학조성에 관하여. 한국생화학회지. 8:89-107.
11. 김재현. 1989. 국산화녹용 분말의 약물활성에 관한 연구. 성균관대학교. 약학 석사학위논문.

12. 김혜영, 류미라. 2000. 국내산 녹용 (Cervi parum Cornu)의 부위별 무기질 조성. 한국식품과학회 지. 32:31-36.

13. 노종식. 1988. A Study of Cervis Elaphus, Ginseng Radix Commelina Communis Aqua-acupuncture. Effects in alloxan-induced diabetic mice. 경희 대 학교. 박사학위논문.

14. 배대식. 1975. 동물의 발육에 미치는 녹용의 효과에 관한 연구. 제1보 녹용의 투여수준이 병아리의 증체량, 사료요구율 및 장기발육에 미치는 영향. 한축지. 17:571-576.

15. 배대식. 1976. 동물의 발육에 미치는 녹용의 효과에 관한 연구. 제2보 녹용의 투여가 병아 리의 장기발육과 혈액상에 미치는 영향. 한축 지 10:342-348.

16. 徐惠波 李延忠 陳蟯光 孫蟯波 王本祥 1992. 鹿茸磷脂抗衰老的 初步研究 中葯藥 理與臨 床 8:29-31

17. 孫星衍神農本草経 集文書局 台北

18. 신국현, 이은방, 김재현, 정명숙, 조성익. 1989. 분말녹용의 약물활성 연구(I). 생약학회지. 20 : 180-187.

19. 안병홍. 1994. 주요산지별 녹용의 영양적 가치 에 관한 연구. 한영사지. 18: 173-178.

20. 오세홍, 이학인. 1987. 녹각이 기아 백서 간장 glucose-6-phosphate dehydro-genase 활성에 미치 는 영향. 대한한의학회지. 8:80-81.

21. 王本祥 陣蟯光 長偉鹿茸 有效成分對 小鼠肝和 蛋白質 合成的影響 藥學學報 25:321-325.

22. 용재익. 1976a. 녹용중의 아미노산 함량에 관 하여. 약학회지. 6:4-9.

23. 용재익. 1976b. 녹용중의 trace element에 관하 여. 약학회지. 6:10-13.

24. 이상목, 이덕윤, 이낙형, 원경종. 1992. 녹용의 효능 및 국내외산 녹용이 랫트의 조혈기능에 미치는 영향에 대한 연구. 건국대학교 동물자 원연구센타 연구보고서.

25. 이상인, 안덕균, 1987. 사슴의 생태와 녹용의 응용. 남산당.

26. 李時診本草綱目 高文社

27. 한나영, 전길자. 1994. 녹용중의 Gangliosides 
분리 및 분석. 한국생화학회지. 27:459-465.

28. 한대석, 김영중, 김진웅, 허훈. 1994. 녹용(생 산, 성분, 효능 및 림상用 | 관한 논문집). 도 서출판 한림원.

29. 한상호. 1970. 녹용이 스트레스(기아, 온열, 한 냉 및 전격)을 받은 흰쥐에 미치는 영향. 카톨 릭의대논문집. 19:157.

30. 허검. 1959. 녹용에 관한 연구. (제 1 보) 녹용의
일반성분에 대하여. 중앙화학 연구보고서.

31. 허검, 최숙형, 이해빈, 정규찬, 고돈이. 1959. 녹용에 관한 연구. (제2보) 녹용 이 실험용 백 서의 성장에 미치는 영향에 대하여. 대한 약 학회지. 5(1):10-15.

32. 許浚東醫寶鑑 堭刷發行 南山堂

33. 許淩東醫靧鑑增刷發行 南山堂

(접수일자 : 2003. 5. 28. / 채택일자 : 2003. 9. 16.) 